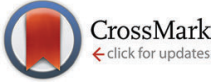

Cite this: New J. Chem., 2016, 40,6564

Received (in Montpellier, France) 27th January 2016,

Accepted 6th June 2016

DOI: 10.1039/c6nj00281a

www.rsc.org/njc

\title{
Visible light-induced monofluoromethylenation of heteroarenes with ethyl bromofluoroacetate $\dagger$
}

\author{
Wei Yu, ${ }^{a}$ Xiu-Hua Xu ${ }^{a}$ and Feng-Ling Qing ${ }^{\star a b}$
}

\begin{abstract}
Visible light-induced monofluoromethylenation of benzofurans and benzothiophenes with ethyl bromofluoroacetate was developed. This method provided a convenient access to novel $\alpha$-fluoro- $\alpha-$ heteroarylesters under mild reaction conditions.
\end{abstract}

Since Fried and Sabo's discovery that the incorporation of a fluorine atom into a corticosteroid derivative led to valuable enhanced biological activity in $1954,{ }^{1}$ fluorinated organic compounds have attracted increasing attention for use in pharmaceuticals and agrochemicals. ${ }^{2}$ The $\alpha$-fluoro- $\alpha$-arylcarboxylic acid moiety is found in many active bioactive compounds ${ }^{3}$ and has been widely used as a building block in organic synthesis. ${ }^{4}$ Consequently, lots of efforts have been made in the preparation of $\alpha$-aryl- $\alpha$-fluorocarbonyl compounds. There are mainly two strategies for the construction of $\alpha$-aryl- $\alpha$-fluorocarbonyl units. The first strategy involves the direct fluorination of $\alpha$-arylcarbonyl derivatives using nucleophilic ${ }^{5}$ or electrophilic ${ }^{6}$ fluorinating reagents. The second strategy involves the condensation reaction of aromatic substrates and fluorine-containing building blocks. ${ }^{7,8}$ Compared to the direct fluorination strategy, the "building block" strategy has been much less explored despite its potential importance. Recently, Sanford ${ }^{7 a}$ as well as Wang and Zhou, ${ }^{7 b}$ respectively, reported the $\mathrm{S}_{\mathrm{N}} \mathrm{Ar}$ reaction of ortho-fluoronitrobenzenes and 2 -fluoromalonates for the preparation of $\alpha$-aryl- $\alpha$-fluoroesters (Scheme 1a). Palladium- ${ }^{8 a, b}$ and nickel-catalyzed ${ }^{8 c}$ cross-coupling reactions of aromatic substrates and fluorine-containing building blocks have provided an efficient strategy to incorporate monofluoromethylene units into aromatic compounds (Scheme 1b). However, both of the methods require the use of prefunctionalized aromatic substrates. The direct monofluoromethylenation of aryl $\mathrm{C}-\mathrm{H}$ bonds remains a big challenge.

\footnotetext{
${ }^{a}$ Key Laboratory of Organofluorine Chemistry, Shanghai Institute of Organic Chemistry, Chinese Academy of Science, Shanghai 200032, China. E-mail: flq@mail.sioc.ac.cn

${ }^{b}$ College of Chemistry, Chemical Engineering and Biotechnology,

Donghua University, Shanghai 201620, China

† Electronic supplementary information (ESI) available: Detailed experimental procedures and analytical data for all new compounds. See DOI: 10.1039/c6nj00281a
}

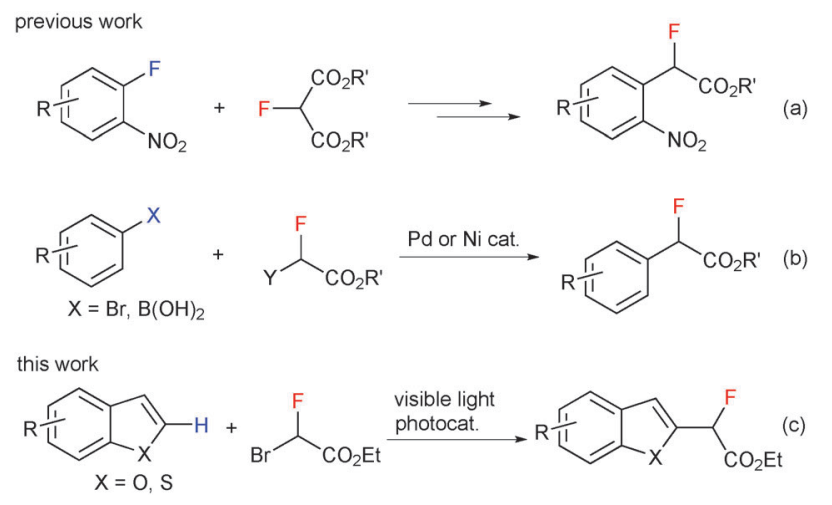

Scheme 1 Monofluoromethylenation of (hetero)aromatic compounds.

Recently, visible light photoredox catalysis has emerged as an efficient and eco-friendly tool in organic synthesis ${ }^{9}$ and has been applied in the fluoroalkylation of organic compounds. ${ }^{10}$ In 2013, we reported a mild and versatile approach for the direct introduction of an ethoxycarbonyldifluoromethyl group into heteroarenes with ethyl bromodifluoroacetate via visible light photocatalysis. ${ }^{11}$ On the basis of that work, we anticipated that a similar transformation with ethyl bromofluoroacetate might allow for the direct introduction of the ethoxycarbonylmonofluoromethyl group into heteroarenes. In continuation of our research interest in visible light-induced fluoroalkylation reactions, ${ }^{10 f, t, w, 11}$ herein we describe the reactions of benzofurans and benzothiophenes with ethyl bromofluoroacetate under visible light photoredox conditions (Scheme 1c). This reaction provides a convenient approach to the synthesis of novel $\alpha$-fluoro- $\alpha$-heteroarylesters.

Initially, we investigated the model reaction of benzofuran 1a with ethyl bromofluoroacetate using blue LEDs as the source of visible light (Table 1). Among the commonly used photocatalysts, only $f a c$-Ir(ppy $)_{3}$ could promote the reaction giving the desired product $2 \mathrm{a}$ in $55 \%$ yield, and no reaction occurred in the presence of $\mathrm{Ru}(\mathrm{bpy})_{3} \mathrm{Cl}_{2} \cdot 6 \mathrm{H}_{2} \mathrm{O}$, methylene blue, or eosin 
Table 1 Optimization of reaction conditions ${ }^{a}$

\begin{tabular}{|c|c|c|c|c|}
\hline & 1) + & $\begin{array}{l}\text { visible light } \\
\text { photocat. } \\
\underset{\text { base, solvent }}{\mathrm{rt}, 12 \mathrm{~h}}\end{array}$ & 2 & \\
\hline Entry & Photocat. & Base & Solvent & Yield $^{b}(\%)$ \\
\hline 1 & $\mathrm{Ru}(\mathrm{bpy})_{3} \mathrm{Cl}_{2} \cdot 6 \mathrm{H}_{2} \mathrm{O}$ & $\mathrm{K}_{2} \mathrm{HPO}_{4}$ & $\mathrm{MeCN}$ & 0 \\
\hline 2 & $f a c-\operatorname{Ir}(\mathrm{ppy})_{3}$ & $\mathrm{~K}_{2} \mathrm{HPO}_{4}$ & $\mathrm{MeCN}$ & 55 \\
\hline 3 & Methylene Blue & $\mathrm{K}_{2} \mathrm{HPO}_{4}$ & $\mathrm{MeCN}$ & 0 \\
\hline 4 & Eosin Y & $\mathrm{K}_{2} \mathrm{HPO}_{4}$ & $\mathrm{MeCN}$ & 0 \\
\hline 5 & {$\left[\operatorname{Ir}(\mathrm{ppy})_{2} \mathrm{Cl}\right]_{2}$} & $\mathrm{~K}_{2} \mathrm{HPO}_{4}$ & MeCN & 29 \\
\hline 6 & {$\left[\operatorname{Ir}(\mathrm{dtbbpy})(\mathrm{ppy})_{2}\right]\left[\mathrm{PF}_{6}\right]$} & $\mathrm{K}_{2} \mathrm{HPO}_{4}$ & $\mathrm{MeCN}$ & 12 \\
\hline 7 & ${\text { fac- } \operatorname{Ir}(\mathrm{ppy})_{3}}$ & $\mathrm{~K}_{2} \mathrm{CO}_{3}$ & $\mathrm{MeCN}$ & 43 \\
\hline 8 & fac-Ir(ppy $)_{3}$ & $\mathrm{~K}_{3} \mathrm{PO}_{4}$ & $\mathrm{MeCN}$ & 52 \\
\hline 9 & $f a c-\operatorname{Ir}(\mathrm{ppy})_{3}$ & KOAc & $\mathrm{MeCN}$ & 23 \\
\hline 10 & $f a c-\operatorname{Ir}(\mathrm{ppy})_{3}$ & $t$-BuONa & $\mathrm{MeCN}$ & 12 \\
\hline 11 & $f a c-\operatorname{Ir}(\mathrm{ppy})_{3}$ & DBU & $\mathrm{MeCN}$ & 21 \\
\hline 12 & $f a c-\operatorname{Ir}(\mathrm{ppy})_{3}$ & DIPEA & $\mathrm{MeCN}$ & 13 \\
\hline 13 & $f a c-\operatorname{Ir}(\mathrm{ppy})_{3}$ & $\mathrm{~K}_{2} \mathrm{HPO}_{4}$ & DMF & 54 \\
\hline 14 & fac- $\operatorname{Ir}(\mathrm{ppy})_{3}$ & $\mathrm{~K}_{2} \mathrm{HPO}_{4}$ & DCM & 46 \\
\hline 15 & $f a c-\operatorname{Ir}(\mathrm{ppy})_{3}$ & $\mathrm{~K}_{2} \mathrm{HPO}_{4}$ & THF & 49 \\
\hline 16 & $f a c-\operatorname{Ir}(\mathrm{ppy})_{3}$ & $\mathrm{~K}_{2} \mathrm{HPO}_{4}$ & $\mathrm{DMF} / \mathrm{H}_{2} \mathrm{O}$ & 74 \\
\hline
\end{tabular}

${ }^{a}$ Reaction conditions: $1 \mathrm{a}(0.1 \mathrm{mmol})$, ethyl bromofluoroacetate $(0.2 \mathrm{mmol})$, photocat. $(0.005 \mathrm{mmol})$, base $(0.2 \mathrm{mmol})$, solvent $(1.0 \mathrm{~mL})$, visible light, rt, under $\mathrm{N}_{2}, 12$ h. ${ }^{b}$ Yields determined by ${ }^{19} \mathrm{~F}$ NMR spectroscopy using fluorobenzene as an internal standard.

$\mathrm{Y}$ (entries 1-4). Other iridium photocatalysts including $\left[\operatorname{Ir}(\mathrm{ppy})_{2} \mathrm{Cl}\right]_{2}$ and $\left[\operatorname{Ir}(\mathrm{dtbbpy})(\mathrm{ppy})_{2}\right]\left[\mathrm{PF}_{6}\right]$ were found to be less effective than fac$\operatorname{Ir}(\mathrm{ppy})_{3}$ (entries 5 and 6). To increase the yield, various inorganic and organic bases including $\mathrm{K}_{2} \mathrm{CO}_{3}, \mathrm{~K}_{3} \mathrm{PO}_{4}$, KOAc, $t$-BuONa, DBU, and DIPEA were tested (entries 7-12). However, none of them gave higher yield. Further screening of different solvents disclosed that DMF, DCM, and THF gave the desired product in slightly lower yields than MeCN (entries 13-15). To our delight, when the reaction was performed in $\mathrm{DMF} / \mathrm{H}_{2} \mathrm{O}$, the yield of $2 \mathrm{a}$ was improved to $74 \%$ (entry 16). It is noteworthy that this optimized yield is much higher than the one obtained in the coupling reaction of benzofuran-2ylboronic acid with ethyl bromofluoroacetate. ${ }^{8 b}$

With the optimized reaction conditions in hand, we next examined the substrate scope of the visible light-promoted direct monofluoromethylenation of heteroarenes (Table 2). A variety of benzofurans 1a-s were employed to give the corresponding 2-monofluoromethylenated products $\mathbf{2 a - s}$ in moderate to excellent yields. The selective formation of 2-substituted isomers is probably due to the generation of a more stable benzylic radical as an intermediate. Different functional groups including ethers, esters, and nitriles were well tolerated. Notably, substrates bearing fluoro, chloro, and bromo substituents on the arene rings are also compatible, thus providing opportunities for additional transformations (1m-1q). With substrates (1r and 1s) containing electronwithdrawing groups, the desired products were isolated in low yields. It is noteworthy that the reaction could be extended to benzothiophenes $\mathbf{1 t}$ and $\mathbf{1} \mathbf{u}$, furnishing products $\mathbf{2 t}$ and $\mathbf{2 u}$ in moderate yields, respectively. The bromofluoromethylenation of indole $1 \mathbf{v}$ gave the desired product $2 \mathbf{v}$ in $47 \%$ yield. However, the electron-rich arene $\mathbf{1 w}$ displayed poor reactivity, with only $22 \%$ of the product being obtained. In the cases of furan and thiophene, low conversion was observed.
Table 2 Substrate scope of photocatalytic monofluoromethylenation of heteroarenes $^{a}$

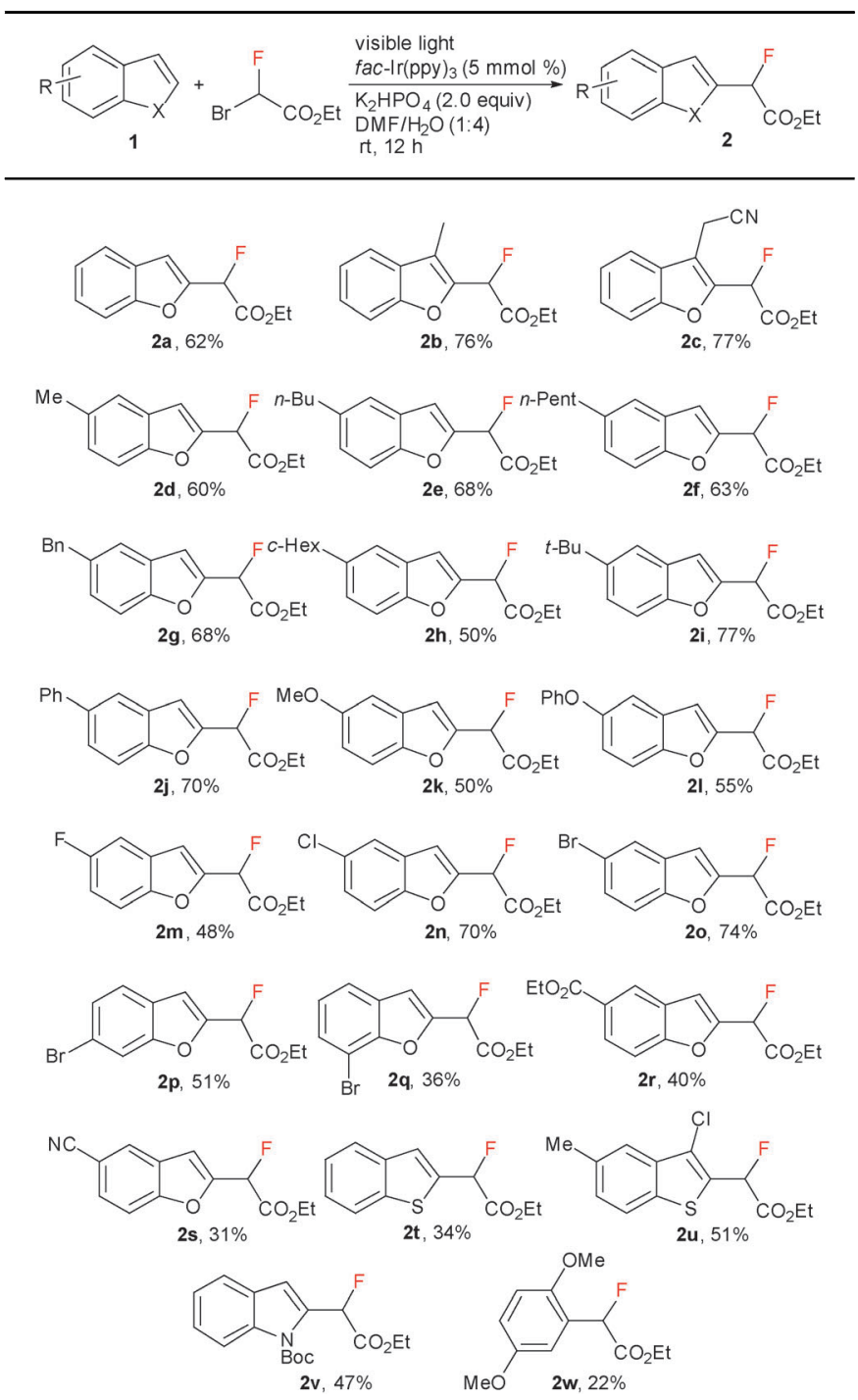

${ }^{a}$ Reaction conditions: 1 (0.5 mmol), ethyl bromofluoroacetate $(1.0 \mathrm{mmol}), f a c-\mathrm{Ir}(\mathrm{ppy})_{3}(0.025 \mathrm{mmol}), \mathrm{K}_{2} \mathrm{HPO}_{4}(1.0 \mathrm{mmol}), \mathrm{DMF} / \mathrm{H}_{2} \mathrm{O}$ $(5.0 \mathrm{~mL})$, visible light, $\mathrm{rt}$, under $\mathrm{N}_{2}, 12 \mathrm{~h}$, isolated yields.

Finally, the control experiments were carried out to gain insights into the reaction mechanism. No reaction took place in the absence of visible light or $f a c$ - $\operatorname{Ir}(\mathrm{ppy})_{3}$, and the addition of 2,2,6,6-tetramethylpiperidine-1-oxyl (TEMPO), a known radical scavenger, could totally inhibit the reaction. Based on the above results and the reported work, ${ }^{10 a, 12}$ a plausible reaction mechanism was proposed as in Scheme 2. Initially, the irradiation of visible light excited $f a c$-Ir ${ }^{\mathrm{III}}(\mathrm{ppy})_{3}$ to $f a c-\mathrm{Ir}^{\mathrm{III}}(\mathrm{ppy})_{3}{ }^{*}$. Then, a single-electrontransfer (SET) from $f a c$-Ir ${ }^{\mathrm{III}}(\mathrm{ppy})_{3}{ }^{*}$ to ethyl bromofluoroacetate generated the radical intermediate $\mathbf{A}$, which was subsequently added to benzofuran $\mathbf{1}$ for the formation of radical intermediate B. Intermediate $\mathbf{B}$ was then oxidized to cation intermediate $\mathbf{C}$, which underwent deprotonation affording the final product 2 .

In conclusion, we have developed a visible light-promoted monofluoromethylenation of heteroarenes with ethyl bromofluoroacetate. This protocol does not require prefunctionalization 


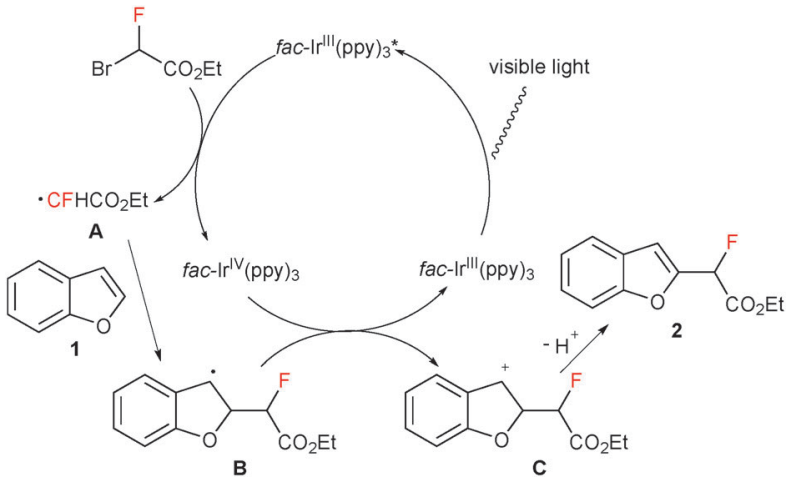

Scheme 2 Proposed reaction mechanism.

of the heteroaromatics and proceeds under mild reaction conditions, which makes it attractive in the preparation $\alpha$-fluoro$\alpha$-heteroarylcarbonyl compounds. The investigation of the present method in the synthesis of biologically active compounds is in progress.

\section{Experimental section}

\section{General procedure for the photocatalytic monofluoromethylenation of heteroarenes}

A $50 \mathrm{~mL}$ Schlenk flask equipped with a rubber septum and a magnetic stir bar was charged with $f a c-\operatorname{Ir}(\mathrm{ppy})_{3}(16.4 \mathrm{mg}$, $0.025 \mathrm{mmol}, 5 \mathrm{~mol} \%$ ), $\mathrm{K}_{2} \mathrm{HPO}_{4}$ (174.1 mg, $1.0 \mathrm{mmol}$, 2.0 equiv.), ethyl bromofluoroacetate ( $184.9 \mathrm{mg}, 1.0 \mathrm{mmol}, 2.0$ equiv.), and heteroarene ( $0.5 \mathrm{mmol}, 1.0$ equiv.). DMF $(1.0 \mathrm{~mL})$ and $\mathrm{H}_{2} \mathrm{O}$ $(4.0 \mathrm{~mL})$ were added to the mixture. Then, the reaction mixture was degassed three times by the freeze-pump-thaw procedure. The flask was placed at a distance of $2 \mathrm{~cm}$ from the blue LEDs. The mixture was stirred under a nitrogen atmosphere and irradiated by blue LEDs for $12 \mathrm{~h}$. After the reaction was complete, the reaction mixture was extracted by $\mathrm{Et}_{2} \mathrm{O}$, and the combined organic phase was dried over anhydrous $\mathrm{Na}_{2} \mathrm{SO}_{4}$. The solvent was removed under vacuum and the residue was purified by column chromatography on silica gel to give the corresponding product.

\section{Acknowledgements}

We thank the National Natural Science Foundation of China (21272036, 21332010 and 21421002) and the National Basic Research Program of China (2012CB21600) for financial support.

\section{Notes and references}

1 J. Fried and E. F. Sabo, J. Am. Chem. Soc., 1954, 76, 1455.

2 (a) K. Muller, C. Faeh and F. Diederich, Science, 2007, 317, 1881; (b) S. Purser, P. R. Moore, S. Swallow and V. Gouverneur, Chem. Soc. Rev., 2008, 37, 320; (c) W. K. Hagmann, J. Med. Chem., 2008, 51, 4359; (d) N. A. Meanwell, J. Med. Chem., 2011, 54, 2529; (e) E. P. Gillis, K. J. Eastman,
M. D. Hill, D. J. Donnelly and N. A. Meanwell, J. Med. Chem., 2015, 58, 8315.

3 Fluorine in Medicinal Chemistry and Chemical Biology, ed. I. Ojima, Wiley, Chichester, 2009.

4 For recent examples, see: (a) A. J. Grenning and J. A. Tunge, Org. Lett., 2010, 12, 740; (b) L. Wu, L. Falivene, E. Drinkel, S. Grant, A. Linden, L. Cavallo and R. Dorta, Angew. Chem., Int. Ed., 2012, 51, 2870; (c) S. Mizuta, I. S. R. Stenhagen, M. O'Duill, J. Wolstenhulme, A. K. Kirjavainen, S. J. Forsback, M. Tredwell, G. Sandford, P. R. Moore, M. Huiban, S. K. Luthra, J. Passchier, O. Solin and V. Gouverneur, Org. Lett., 2013, 15, 2648; (d) K. Araki, T. Katagiri and M. Inoue, J. Fluorine Chem., 2014, 157, 41; (e) J. Alvarado, A. T. Herrmann and A. Zakarian, J. Org. Chem., 2014, 79, 6206; $(f)$ D. W. Manley and J. C. Walton, Org. Lett., 2014, 16, 5394.

5 (a) S. Hamman, M. Barrelle, F. Tetaz and C. G. Beguin, J. Fluorine Chem., 1987, 37, 85; (b) E. Laurent, B. Marquet, R. Tardivel and H. Thiebault, Tetrahedron Lett., 1987, 28, 2359; (c) S. Watanabe, T. Fujita, M. Sakamoto, H. Endo and T. Kitazume, J. Fluorine Chem., 1990, 47, 187; (d) C.-S. Tsai, Y.-K. Li and L.-C. Lo, Org. Lett., 2002, 4, 3607; (e) V. Dinoiu, T. Fukuhara, K. Miura and N. Yoneda, J. Fluorine Chem., 2003, 121, 227; $(f)$ J. Yin, D. S. Zarkowsky, D. W. Thomas, M. M. Zhao and M. A. Huffman, Org. Lett., 2004, 6, 1465; $(g)$ T.-H. Shie, Y.-L. Chiang, J.-J. Lin, Y.-K. Li and L.-C. Lo, Carbohydr. Res., 2006, 341, 443; (h) K.-Y. Kim, B. C. Kim, H. B. Lee and H. Shin, J. Org. Chem., 2008, 73, 8106; (i) X. Zhao, W. Zhuang, D. Fang, X. Xue and J. Zhou, Synlett, 2009, 779; $(j)$ I. E. Kopka, L. S. Lin, J. P. Jewell, T. J. Lanza, T. M. Fong, C.-P. Shen, Z. J. Lao, S. Ha, L. G. Castonguay, L. V. der Ploeg, M. T. Goulet and W. K. Hagmann, Bioorg. Med. Chem. Lett., 2010, 20, 4757; $(k)$ T. Sawamura, S. Kuribayashi, S. Inagi and T. Fuchigami, Org. Lett., 2010, 12, 644.

6 (a) W. J. Middleton and E. M. Bingham, J. Am. Chem. Soc., 1980, 102, 4845; (b) T. Umemoto, K. Kawada and K. Tomita, Tetrahedron Lett., 1986, 27, 4465; (c) S. T. Purrington and D. L. Woodard, J. Org. Chem., 1990, 55, 3423; (d) F. A. Davis, W. Han and C. K. Murphy, J. Org. Chem., 1995, 60, 4730; (e) S. Rozen, A. Hagooly and R. Harduf, J. Org. Chem., 2001, 66, 7464; $(f)$ H. Fujisawa and Y. Takeuchi, J. Fluorine Chem., 2002, 117, 173; $(g)$ F. Zhang and J. Z. Song, Tetrahedron Lett., 2006, 47, 7641; (h) T. Suzuki, Y. Hamashima and M. Sodeoka, Angew. Chem., Int. Ed., 2007, 46, 5435; (i) D. H. Paull, M. T. Scerba, E. Alden-Danforth, L. R. Widger and T. Lectka, J. Am. Chem. Soc., 2008, 130, 17260; $(j)$ I. T. Schiefer, S. Abdul-Hay, H. Wang, M. Vanni, Z. Qin and G. R. J. Thatcher, J. Med. Chem., 2011, 54, 2293; ( $k$ ) F. Li, Z. Wu and J. Wang, Angew. Chem., Int. Ed., 2015, 54, 656.

7 (a) A. Harsanyi, G. Sandford, D. S. Yufit and J. A. K. Howard, Beilstein J. Org. Chem., 2014, 10, 1213; (b) F. Zhu, P.-W. Xu, F. Zhou, C.-H. Wang and J. Zhou, Org. Lett., 2015, 17, 972.

8 (a) N. A. Beare and J. F. Hartwig, J. Org. Chem., 2002, 67, 541; (b) C. Guo, X. Yue and F.-L. Qing, Synthesis, 2010, 1837; 
(c) Y.-M. Su, G.-S. Feng, Z.-Y. Wang, Q. Lan and X.-S. Wang, Angew. Chem., Int. Ed., 2015, 54, 6003.

9 (a) T. P. Yoon, M. A. Ischay and J. Du, Nat. Chem., 2010, 2, 527; (b) J. M. R. Narayanam and C. R. J. Stephenson, Chem. Soc. Rev., 2011, 40, 102; (c) J. Xuan and W.-J. Xiao, Angew. Chem., Int. Ed., 2012, 51, 6828; (d) C. K. Prier, D. A. Rankic and D. W. C. MacMillan, Chem. Rev., 2013, 113, 5322; (e) D. A. Nicewicz and T. M. Nguyen, ACS Catal., 2014, 4, 355. 10 For recent examples, see: (a) J. Jung, E. Kim, Y. You and E. J. Cho, Adv. Synth. Catal., 2014, 356, 2741; (b) N. Iqbal, J. Jung, S. Park and E. J. Cho, Angew. Chem., Int. Ed., 2014, 53, 539; (c) P. Xu, A. Abdukader, K. Hu, Y. Cheng and C. Zhu, Chem. Commun., 2014, 50, 2308; (d) W. Li, X. Zhu, H. Mao, Z. Tang, Y. Cheng and C. Zhu, Chem. Commun., 2014, 50, 7521; (e) M. Rueda-Becerril, O. Mahé, M. Drouin, M. B. Majewski, J. G. West, M. O. Wolf, G. M. Sammis and J.-F. Paquin, J. Am. Chem. Soc., 2014, 136, 2637; ( $f$ ) Q.-Y. Lin, X.-H. Xu and F.-L. Qing, J. Org. Chem., 2014, 79, 10434; (g) Y. Yasu, Y. Arai, R. Tomita, T. Koike and M. Akita, Org. Lett., 2014, 16, 780; $(h)$ D. Cantillo, O. de Frutos, J. A. Rincón, C. Mateos and C. O. Kappe, Org. Lett., 2014, 16, 896; ( $i$ ) A. Carboni, G. Dagousset, E. Magnier and G. Masson, Org. Lett., 2014, 16, 1240; $(j)$ S. H. Oh, Y. R. Malpani, N. Ha, Y.-S. Jung and S. B. Han, Org. Lett.,
2014, 16, 1310; ( $k$ ) J. Xie, X. Yuan, A. Abdukader, C. Zhu and J. Ma, Org. Lett., 2014, 16, 1768; (l) X. Sun and S. Yu, Org. Lett., 2014, 16, 2938; (m) Y.-M. Su, Y. Hou, F. Yin, Y.-M. Xu, Y. Li, X. Zheng and X.-S. Wang, Org. Lett., 2014, 16, 2958; (n) L. Wang, X.-J. Wei, W.-L. Jia, J.-J. Zhong, L.-Z. Wu and Q. Liu, Org. Lett., 2014, 16, 5842; (o) X.-J. Tang and W. R. Dolbier, Jr., Angew. Chem., Int. Ed., 2015, 54, 4246; (p) R. Tomita, T. Koike and M. Akita, Angew. Chem., Int. Ed., 2015, 54, 12923; (q) X.-J. Tang, Z. Zhang and W. R. Dolbier, Chem. - Eur. J., 2015, 21, 18961; (r) A. Singh, J. J. Kubik and J. D. Weaver, Chem. Sci., 2015, 6, 7206; (s) J. W. Beatty, J. J. Douglas, K. P. Cole and C. R. J. Stephenson, Nat. Commun., 2015, 6, 7979; $(t)$ Q.-Y. Lin, X.-H. Xu and F.-L. Qing, Org. Biomol. Chem., 2015, 13, 8740; (u) Z. Zhang, X. Tang, C. S. Thomoson and W. R. Dolbier, Jr., Org. Lett., 2015, 17, 3528; (v) Z. Zhang, X. Tang and W. R. Dolbier, Jr., Org. Lett., 2015, 17, 4401; (w) Q.-Y. Lin, X.-H. Xu, K. Zhang and F.-L. Qing, Angew. Chem., Int. Ed., 2016, 55, 1479; (x) Y. Arai, R. Tomita, G. Ando, T. Koike and M. Akita, Chem. - Eur. J., 2016, 22, 1262.

11 Q.-Y. Lin, L. Chu and F.-L. Qing, Chin. J. Chem., 2013, 31, 885 .

12 J. D. Nguyen, J. W. Tucker, M. D. Konieczynska and C. R. J. Stephenson, J. Am. Chem. Soc., 2011, 133, 4160. 